\title{
Variable Growth Across Species and Life Stages in Caribbean Reef Octocorals
}

\author{
Natascha Borgstein, Diana M. Beltrán and Carlos Prada* \\ Department of Biological Sciences, The University of Rhode Island, Kingston, RI, United States
}

Growth rates often measured as linear extension rates can serve as a proxy for organismal performance across environments, yet few estimates of these growth rates exist, and fewer are reported from multi-year monitoring. We studied the effect of species, depth, exposure, and life stages on the linear extension rates of common octocorals inhabiting Caribbean reefs. We monitored 16 species from the families Briareidae, Gorgoniidae, and Plexauridae, including eight genera: Antillogorgia, Briareum, Eunicea, Gorgonia, Muricea, Muriceopsis, Plexaura, and Plexaurella. We surveyed over 2,000 colonies across eight reefs in Southwest Puerto Rico from 2003 to 2006. Our surveys include reefs along a gradient of water motion from inside protected reefs to offshore unprotected reefs and from shallow $(5 \mathrm{~m})$ forereefs to

OPEN ACCESS

Edited by: Stefano Goffredo, University of Bologna, Italy

Reviewed by:

Georgios Tsounis, California State University, Northridge,

United States

Pamela Hallock, University of South Florida,

United States

*Correspondence:

Carlos Prada

prada@uri.edu

Specialty section:

This article was submitted to

Coral Reef Research,

a section of the journal

Frontiers in Marine Science

Received: 11 July 2019

Accepted: 28 May 2020

Published: 24 June 2020

Citation:

Borgstein N, Beltrán DM and Prada C (2020) Variable Growth Across Species and Life Stages in Caribbean Reef Octocorals.

Front. Mar. Sci. 7:483.

doi: 10.3389/fmars.2020.00483 deeper environments reaching $25 \mathrm{~m}$. We observed that linear extension rates vary across species and largely follow branch thickness variation and colony architecture, with thin plume-like shapes growing faster. We also found that in 7 out of the 16 species, colonies from shallow habitats with brighter and warmer environments have higher growth rates than colonies in deep, low energy, and darker areas. Importantly, small/juvenile corals of most species $(<10 \mathrm{~cm})$ grew faster than adult colonies. Our data highlight the possibility that, as climate change continues to deteriorate Caribbean reefs by decimating scleractinian corals and opening new habitat for less vulnerable species, plume-like corals with fast growth rates such as species within the genus Antillogorgia may become the most abundant benthic cnidarians on Caribbean shallow forereefs.

Keywords: octocorals, Caribbean, depth, coral conservation, growth, size dependent growth, growth rates

\section{INTRODUCTION}

Coral reefs contribute more than $25 \%$ of the biodiversity in the sea, supporting hundreds of thousands of species that depend on them for nourishment and shelter (Sala and Knowlton, 2006). Coastal communities depend on the biodiversity of reefs for their food and economy through artisanal fisheries and tourism, as well as for shoreline protection from hurricanes (Wells et al., 2006; Costanza et al., 2014). Despite the extensive services that reefs provide to humans, these ecosystems are declining across the world at an alarming rate due mainly to human activities, our excessive release of carbon dioxide and our oil-based economy (Pandolfi et al., 2005; Edmunds, 2013; Jackson et al., 2014; Cortés and Reyes-Bonilla, 2017; Hughes et al., 2018). Given the environmental crisis faced by coral reefs today, it is imperative to learn as much as possible from their basic biology and apply it to enhance coral conservation.

The Caribbean is one of the reef areas most affected by anthropogenic activities with coral cover now below 15\% (Edmunds, 2013; Ruzicka et al., 2013; Jackson et al., 2014; 
Tsounis and Edmunds, 2017). Recent studies suggest that not only scleractinians are dying but also reef communities have changed (Green et al., 2008; Edmunds, 2013; Edmunds and Lasker, 2016; Tsounis and Edmunds, 2017). Caribbean reefs have experienced a sharp decline of scleractinian corals and an increase of octocoral populations in the last 50 years (Ruzicka et al., 2013; Lenz et al., 2015). Accordingly, octocorals are becoming dominant in shallow forereefs, replacing scleractinian hard corals (Ateweberhan et al., 2013; Ruzicka et al., 2013; Gómez et al., 2015; Lenz et al., 2015; Edmunds and Lasker, 2016; Tsounis and Edmunds, 2017).

The increased dominance of octocoral species on Caribbean reefs has been documented in different areas such as in the Florida Keys, Puerto Rico, and St. John, U.S. Virgin Islands (Ruzicka et al., 2013; Lenz et al., 2015; Edmunds and Lasker, 2016; Williams et al., 2017). The causes of the sustained increase in octocoral abundance remains unclear, but the increase in abundance suggest that octocorals are more resilient, than scleractinians, to contemporary degradation of marine habitats as a result of human activities. One reason for the increase in octocoral abundance in comparison to hard corals is a reduced effect of climate change due to their lower carbonate needs for growth, and also their apparent higher tolerance to bleaching events (Prada et al., 2010; Gabay et al., 2014; Goulet et al., 2017). To better understand how environmental change will further alter reef organisms, and reveal why octocorals are so successful under these stressful conditions, it is essential to study their basic biology.

One way to understand why octocorals are being aided by environmental variation in recent decades is by studying variation in growth rates. Coral growth is a key indicator of the performance of an individual within a given environment (Anderson et al., 2017). While several studies exist on variation in growth rates in scleractinian corals (Hubbard and Scaturo, 1985; Huston M., 1985; Lough and Cantin, 2014; Forsman et al., 2015), few studies have quantified growth rates in Caribbean octocorals (Yoshioka and Yoshioka, 1991; Brazeau and Lasker, 1992; Cadena and Sánchez, 2010) and none have considered their variation across environments. This study fills this gap by quantifying variation in linear extension rates of Caribbean octocorals across environmental gradients and colony sizes.

Two associated factors that influence linear extension rates are depth and light levels (Huston M.A., 1985). Across depths, scleractinian corals grow faster in the luminous waters of shallow forereefs where water clarity, photosynthesis and energy from their algal symbionts is highest (Huston M.A., 1985). Growth rates slow down as depth increases, likely as a result of lower energy coming from photosynthesis associated with the exponential decay of light (Huston M.A., 1985). In the shallower depths, corals are subjected to a broader range on the light spectrum, which has been shown to decrease their susceptibility to photoinhibition, meaning they are less likely to be affected by photooxidative stress and more able to focus on optimal larval settlement, spatial arrangement, and interspecific competition (Ben-Zvi et al., 2020). All other factors being equal, brighter environment should increase growth but the relationship is not straight forward, as in some cases, feeding from particulate matter in organisms in deeper environments can offset the lack of light and in some others photo-inhibition can occur (Lesser et al., 2010). It is uncertain if these general trends of increased growth rates in shallow, brighter areas for scleractinian corals is also applicable to octocorals. In addition, exposure to water movement, which is often associated with higher number of organic particles and food, has been associated with faster growth rates in temperate soft corals (Sebens and Done, 1992). Yet it is unknown if this also occurs in tropical octocorals.

Another aspect that correlates with changes in linear extension rates is colony architecture. In scleractinian corals, growth rates vary across different colony forms with arborescent branching forms often growing faster vertically than massive forms (Anderson et al., 2017; Cabral-Tena et al., 2018). Differences occur as massive forms require more calcium carbonate to increase vertically (Anderson et al., 2017; Cabral-Tena et al., 2018). In branching forms, the thickness of the branches as well as the porosity of the skeleton allow some species to vertically grow faster. Anthozoans with porous skeletons, such as acroporids, grow faster than corals with dense skeletons (Huston M., 1985; Hoegh-Guldberg et al., 2008). In octocorals there are fewer reports on growth rates and most are for colonies in the genus Antillogorgia (Yoshioka, 1998; Castanaro and Lasker, 2003; Cadena and Sánchez, 2010) with some exceptions (Brazeau and Lasker, 1992; Viladrich et al., 2018), and no comparative studies exist across species with different morphologies and branch thicknesses.

Along with colony form, both colony size and age can affect growth rates in anthozoans. Coral-reef organisms compete fiercely for space, so this growth is essential for their survival (Sebens, 1983). One of the most vulnerable stages of reef organisms is the juvenile stage. To limit such vulnerability, corals prioritize growth (clonal propagation) over sexual reproduction during early life (Connell, 1973; Hughes and Jackson, 1985; Viladrich et al., 2017). Once colonies acquire larger sizes, colonies switch to prioritizing sexual reproduction, as sexual reproduction and growth are considered competing biological functions of corals (Chornesky and Peters, 1987; Beiring and Lasker, 2000). This differential investment of resources from vegetative growth early on to sexual reproduction later on, generates a pattern in which small, younger colonies often grow faster than older, larger, and mature colonies (Hughes and Connell, 1987). Understanding whether this pattern applies solely to scleractinian corals or if it can be applied more generally to anthozoans is of utmost importance to enhance coral restoration (Hagedorn et al., 2018). More importantly, understanding the differences in linear extension rates across species and size may enhance predictions of how reefs will change ecologically as human impacts continue.

Here we quantified variation in linear extension rates across depth, exposure and size across 16 octocoral species with different morphologies, some of which are becoming the most dominant species in most Caribbean forereefs. We compiled over 2,000 observations of linear extension of octocoral colonies from 2003 to 2006 to determine if: (1) different species with different morphologies have different growth rates; (2) if smaller (presumably younger) colonies grow faster than larger, sexually mature colonies; (3) if colonies in shallow, brighter areas grow 


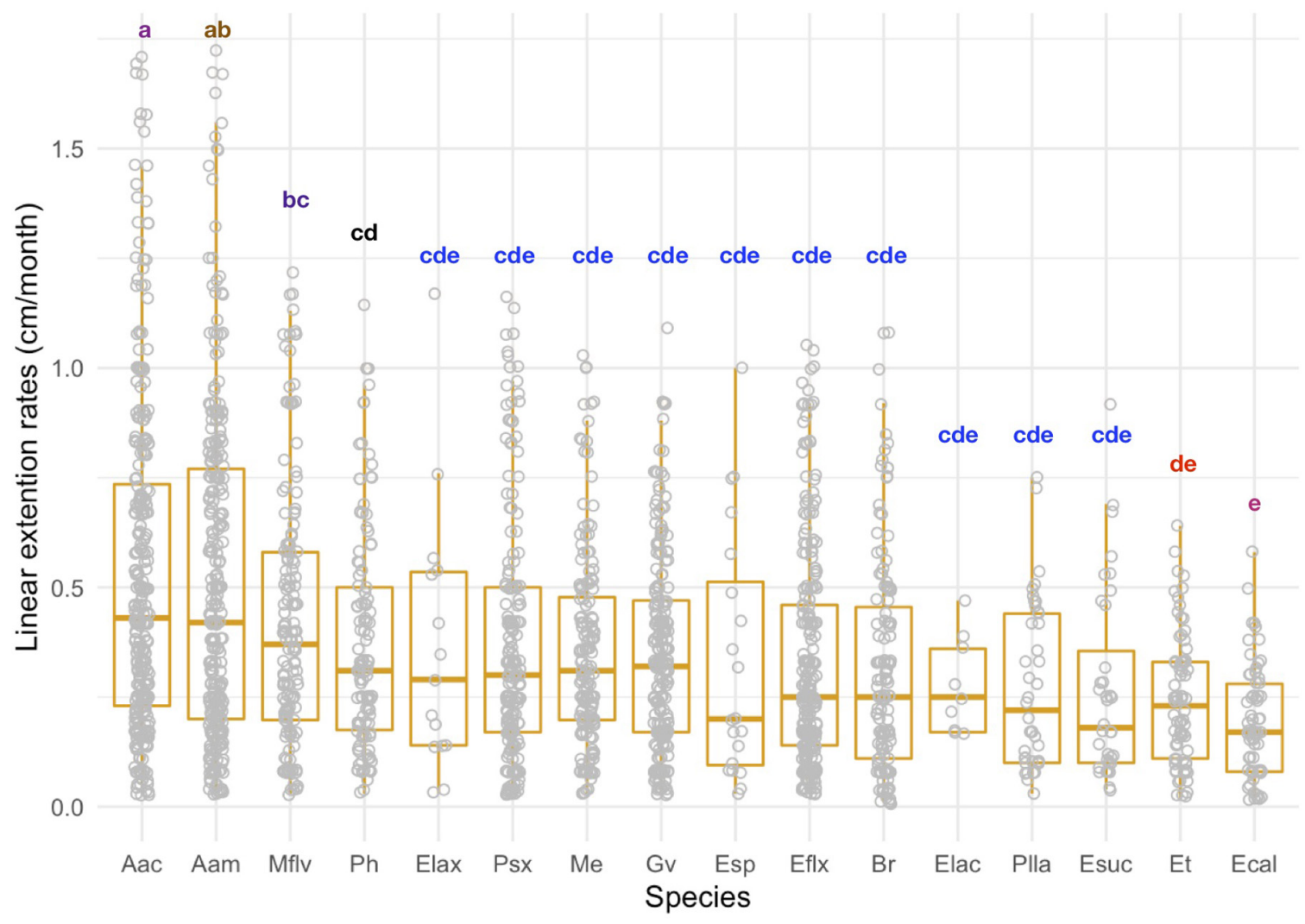

FIGURE 1 | Linear extension rates (cm/month) for individual colonies across 16 Caribbean octocoral species. Boxplots shows median values and upper (75) and lower (25) quantiles. Letters indicate significant differences among groups.

faster than in deeper, darker areas; and (4) if species with thinner branches achieve faster vertical growth than thicker colonies. Understanding the rate at which different octocoral species grow is key to understanding if certain species that are becoming dominant on Caribbean reefs do so, in part, due to their fast vertical growth.

\section{MATERIALS AND METHODS}

\section{Field Measurements}

To understand variation in linear extension rates across species, we measured colonies annually from 2003 to 2006 at eight reefs in La Parguera, Puerto Rico, that have been monitored since 2001 as part of a NOAA CRES site (Ballantine et al., 2008). The reefs are distributed along a gradient from inshore: Romero (Rom; $17^{\circ} 56.2^{\prime} \mathrm{N}, 66^{\circ} 59.4^{\prime} \mathrm{W}$ ), Enrique (En; $17^{\circ} 56.7^{\prime} \mathrm{N}, 67^{\circ}$ $02.2^{\prime} \mathrm{W}$ ), Pelotas (Pel; $17^{\circ} 57.4^{\prime} \mathrm{N}, 67^{\circ} 04.2^{\prime} \mathrm{W}$ ); to midshelf reefs: Turrumote (Tur; $17^{\circ} 56.1^{\prime} \mathrm{N}, 67^{\circ} 01.1^{\prime} \mathrm{W}$ ), Media Luna (ML; $17^{\circ} 56.1^{\prime} \mathrm{N}, 67^{\circ} 02.9^{\prime} \mathrm{W}$ ), San Cristobal (SC; $17^{\circ} 56.5^{\prime} \mathrm{N}, 67^{\circ}$ $04.5^{\prime} \mathrm{W}$ ), ending with offshore shelf edge sites: El Hoyo (Hoy; $17^{\circ} 52.6^{\prime} \mathrm{N}, 67^{\circ} 02.6^{\prime} \mathrm{W}$ ) and Weinberg (Wein; $17^{\circ} 53.4^{\prime} \mathrm{N}, 67^{\circ}$ $\left.59.3^{\prime} \mathrm{W}\right)$. Within each reef location we sampled colonies across three (shallow, mid, and deep) depths except in offshore shelf edge sites, where only deep areas are available. The ranges of the three sampled depths per site in meters were : Enrique: 23, 7-8, 10-11; Pelotas: 2-3, 7-8, 11-12; San Cristobal: 2-3, 8-9, 14-15; Media Luna: 4-5, 11-12, 15-18; Romero: 2-3, 8-9, 1314; Turrumote: 3-4, 9-10, 14-16; El Hoyo: 22-24; and Weinberg: 20-25. Those three depths roughly follow the reef terrace (the uppermost part of the reef closest to the shore and protected from wave action), reef break (the highest point of the reef which causes the waves to break), and deep forereef (steep downwards slope). The area has been fully described and routinely studied to monitor variation in species composition of reef organisms (Ballantine et al., 2008; Yoshioka, 2009; Williams et al., 2017).

At each depth, we sampled two permanent transects parallel to depth profiles. To quantify variation in liner extension rates and resample colonies across time, we monitored permanent $1 \mathrm{~m} \times 1 \mathrm{~m}$ quadrats in each of the replicate transects. All quadrats were permanently defined by nails. Colonies were identified to the lowest taxonomic level feasible based on field characteristics following Sanchez and Wirshing (2005), and verified by microscopic examinations of sclerites in the laboratory when necessary, following Bayer (1961). We considered juveniles to be $<10 \mathrm{~cm}$ in height, as that is the size at which mortality rates decrease to become comparable with that of adults (Yoshioka, 1998). Colonies $<10 \mathrm{~cm}$ die more often (Yoshioka and Yoshioka, 1991; Yoshioka, 1998). Our monitored taxa include (Supplementary Table S1): Briareum 


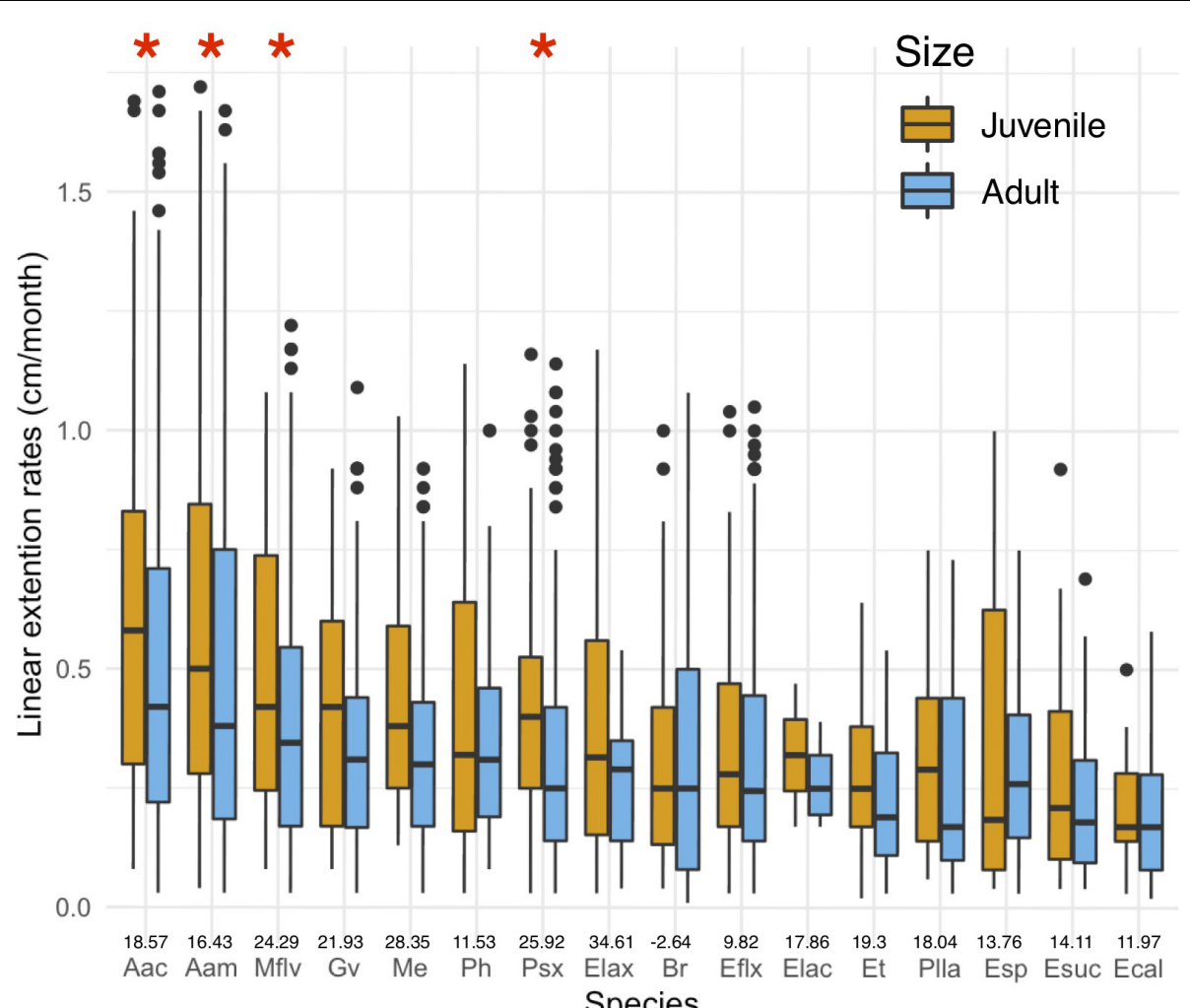

FIGURE 2 | Differences in juvenile and adult linear extension rates (cm/month) per species. Boxplots shows median values and upper (75) and lower (25) quantiles. Asterisks represent significant differences. Values above names represent percent increase in growth rates of small/juveniles over adult colonies.

asbestinum (Br), Eunicea calyculata (Ecal), Eunicea laciniata (Elac), Eunicea laxispica (Elax), Eunicea spp. (Esp), Eunicea succinea (Esuc), Eunicea tourneforti (Et), Gorgonia ventalina (Gv), Muricea elongata (Me), Muriceopsis flavida (Mflv), Antillogorgia acerosa (Aac), Antillogorgia americana (Aam), Eunicea flexuosa (Eflx), Plexaura homomalla (Ph), Plexaurella spp. (Plla), and Pseudoplexaura spp. (Psx).

\section{Statistical Analysis}

To quantify variation in growth rates, we measured linear extension using wooden rulers bi-annually. We measured colonies directly in the field from the bottom to the highest point in the colony. We based our observations on the height of the colony and thus did not measure individual branches. We did not observe major disease events. Because growth rates could be altered by predation (i.e., decrease in size), we also eliminated all colonies for which we observed a decrease in linear extension. In other cases, the overall changes in growth rate were outside of reasonable ranges for the particular species, thus to avoid confounding factors, we eliminated all those colonies as well. Our final dataset consisted of 2,013 colonies.

We calculated linear extension rates (in $\mathrm{cm} /$ month) by subtracting the final measurement from the initial measurement and dividing by the intervening number of months. In most cases the total time was 36 months, but in others we only used part of the data as we were unable to sample all colonies at the 36th month, so we divided accordingly by the number of months in each specific case. To compare the effects of species, size, reefs, depth, and exposure on the linear extension, we used monthly rates and analyzed them using generalized least square (GLS) models in R (v. 3.3.4; R Development Core Team, 2008) with the package nlme (Pinheiro et al., 2012) with a previous test of normality. In each case, we used model selection to sequentially test GLS models via likelihood ratio tests to obtain the optimal fixed structure for each model following Zuur et al. (2009). We initially tried models with the function varIdent to control for heteroscedasticity, but those models resulted in poorer fit. After we found the best model, we tested for the significance of the remaining fixed terms using likelihood ratio tests. We then used the multcomp package (Hothorn et al., 2008) to test for differences among treatments using the generalized linear hypothesis test (glht) and Tukey (HSD). We also used the R package agricolae (De Mendiburu, 2009) to generate different letter groups when testing differences in growth rates and thickness among species.

Because colony size was a major driver of variation in the linear extension rates among colonies, we estimated the percent increase of juveniles over adults by calculating the difference between the mean value of the two rates and dividing by the juvenile growth rate times 100 ([juvenile - adult] $\times 100 /$ juvenile). To understand the relationship between linear extension rates and branch thickness we measured the thickness of ten branches 


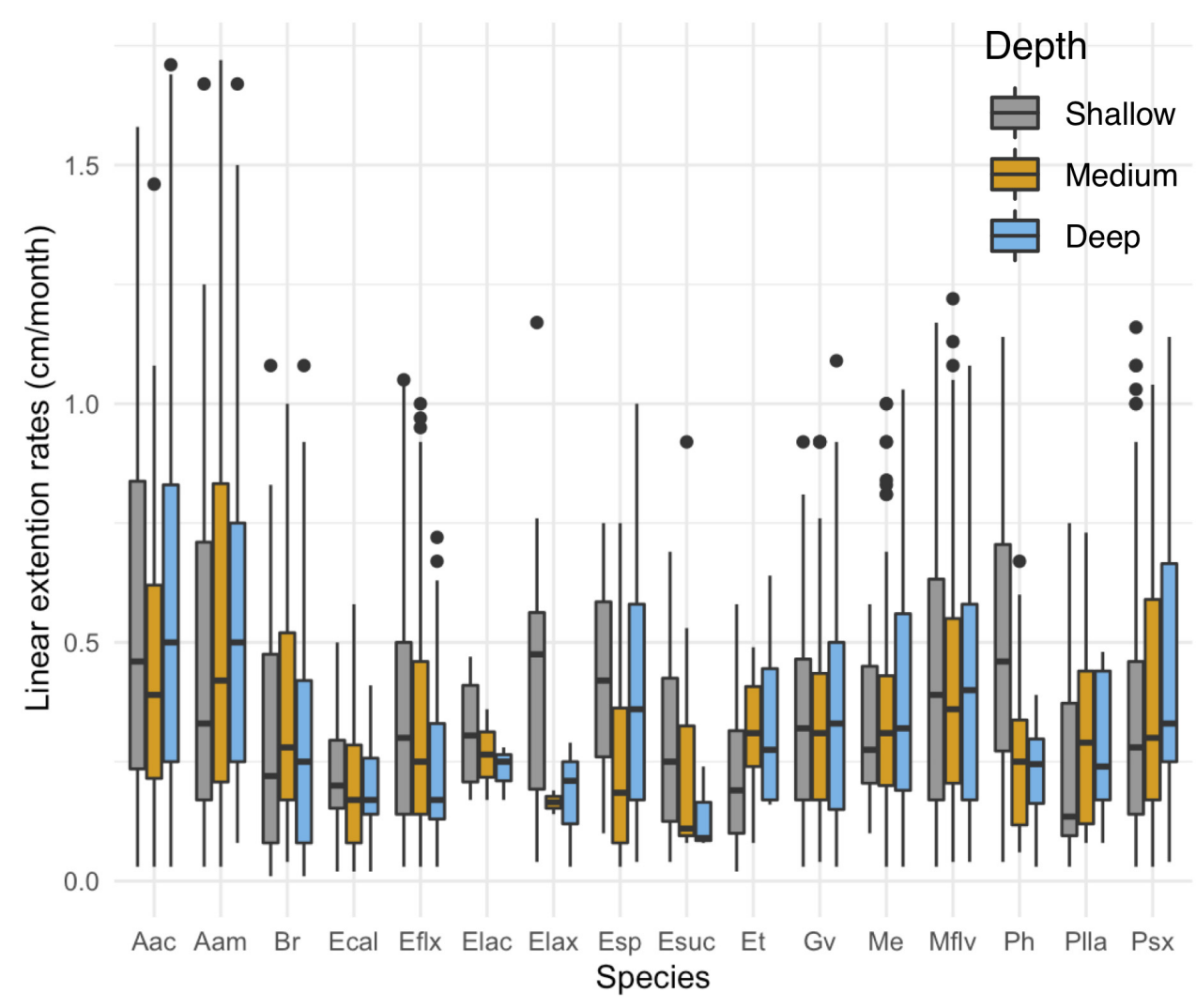

FIGURE 3 | Differences in mean growth rate (cm/month) across depths per species. Boxplots shows median values and upper (75) and lower (25) quantiles.

per species collected from the same reefs as the colonies sampled for growth rates. We measured each colony using a caliper with a $0.01 \mathrm{~mm}$ accuracy on dry specimens. We then estimated correlations between linear extension rates and branch thickness in $\mathrm{R}$ using the geom_smooth function. We did not use branch thickness in the above GLS model along with species, depth, size, reef, and exposure because our measurements are from different colonies than the ones measured for linear extension rate.

\section{RESULTS}

Octocorals were common in the sampled area with $>8$ colonies $/ \mathrm{m}^{2}$. Our 2,013 monitored colonies were distributed evenly across depths (674 shallow; 707 medium, and 632 deep) with more colonies in inshore (827) and mid shore (848) areas and fewer in offshore areas (338). We sampled more adult $(1,482)$ than small colonies (531) and all species were present across all depths, exposure levels and sizes.

Linear extension rates varied greatly among Caribbean shallow water octocorals (Figure 1). The major factors driving differences in linear extension rates were species and size (Table 1) and in fact the best model to explain differences in linear extension rates included only species and size as factors (AIC $=818, p=0.004$; Supplementary Table S1). The fastest growing species were the plume-like species Antillogorgia acerosa and $A$. americana with a mean rate of $0.53(\mathrm{SD}=0.38)$ and $0.51(\mathrm{SD}=0.37) \mathrm{cm} / \mathrm{month}$ ) (Figure 1), respectively. Among the slower growing species were: E. calyculata, E. tourneforti,

TABLE 1 | Full generalized least square (GLS) model across species, depth, exposure and age (top) and best model (bottom).

\begin{tabular}{lccc}
\hline \multicolumn{1}{c}{ numDF } & $\boldsymbol{F}$-value & $\boldsymbol{p}$-value \\
\hline Full model (Species, Size, Exposure and Depth) & \\
Intercept & 1 & $3,578.340$ & $<0.0001$ \\
Species & 15 & 13.943 & $<0.0001$ \\
Size & 1 & 27.244 & $<0.0001$ \\
Exposure & 2 & 0.992 & 0.3712 \\
Depth & 2 & 0.945 & 0.3887 \\
Species:Size & 15 & 0.514 & 0.9343 \\
Species:Exposure & 30 & 0.730 & 0.8558 \\
Size:Exposure & 2 & 0.185 & 0.8314 \\
Species:Depth & 30 & 2.262 & 0.0001 \\
Size:Depth & 2 & 3.338 & 0.0358 \\
Exposure:Depth & 4 & 0.914 & 0.4551 \\
Species:Size:Exposure & 30 & 0.617 & 0.9486 \\
Species:Size:Depth & 30 & 1.261 & 0.1572 \\
Best model (Species and Size) & & & \\
Intercept & 1 & $3,672.025$ & $<0.0001$ \\
Species & 15 & 14.308 & $<0.0001$ \\
Size & 1 & 27.957 & $<0.0001$
\end{tabular}




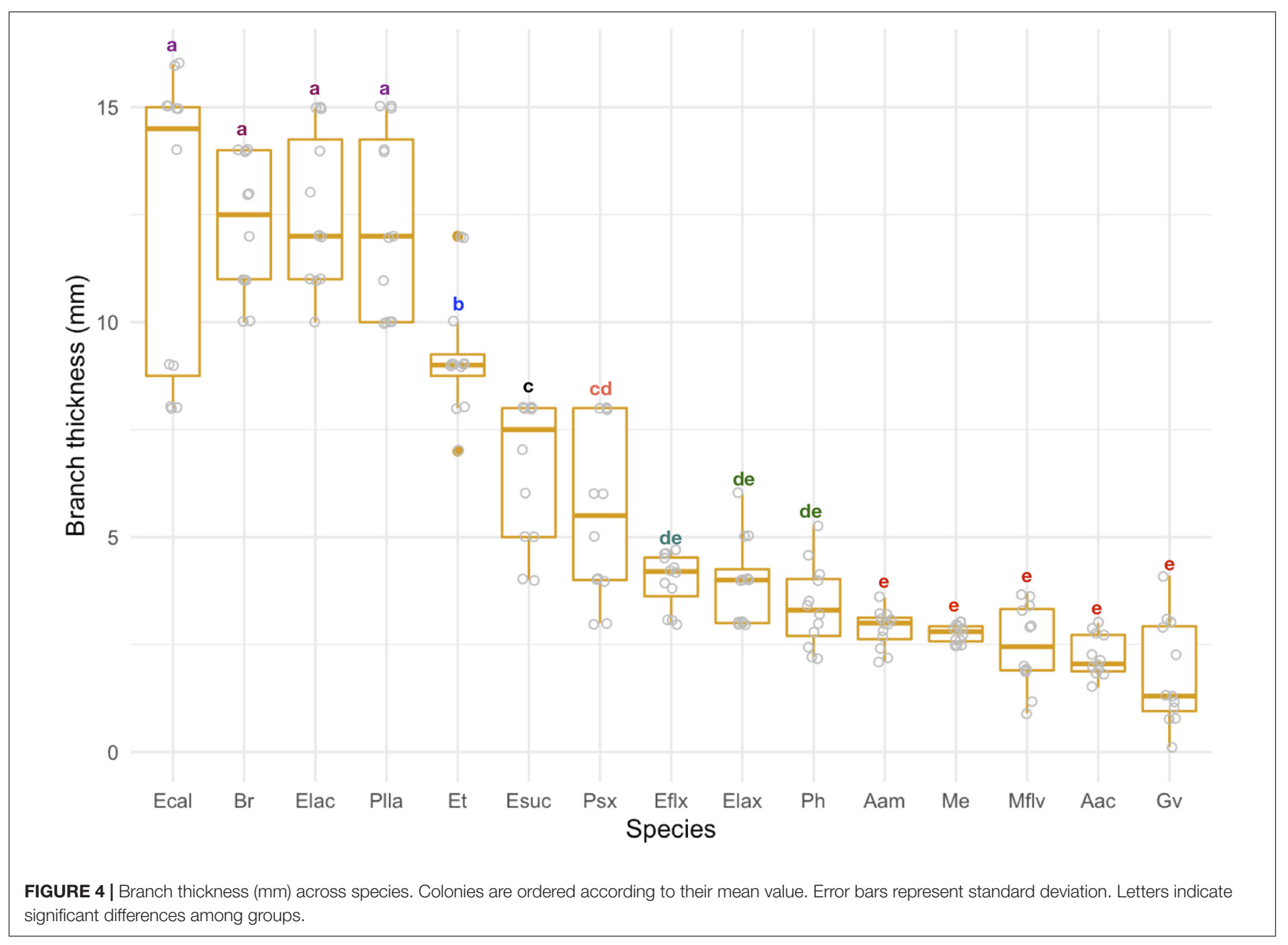

and E. laciniata with a mean growth rate of $0.20(\mathrm{SD}=0.13)$, $0.24(\mathrm{SD}=0.15)$ and $0.27(\mathrm{SD}=0.11) \mathrm{cm} / \mathrm{month}$, respectively (Figure 1). Thirteen out of the 16 species (except B. asbestinum, E. calyculata, and Eunicea spp.) showed a trend towards having a higher growth rate in juveniles in comparison to adults (Figure 2). The average increase of small/juveniles over adults is $17.7 \%$ (Figure 2).

While depth or exposure did not have a major effect on linear extension rate variation (lower fit to our data), the interaction between species and depth is significant in the full model (Table 1). There is a tendency of seven species (E. calyculata E. lacinata, E. laxispica, Eunicea sp. E. succinea, E. flexuosa, and $P$. homomalla) to grow faster on shallower environments (Figure 3). Exceptions to this were: A. acerosa, A. americana, $G$. ventalina, $M$. elongata, and Pseudoplexaura spp., which had higher average growth rates in deeper habitats. The B. absetinum, E. tourneforti, and Plexaurella spp. showed highest average growth at intermediate depths (Figure 3).

We found significant variation in branch thickness across species ranging from 1.8 to $12.6 \mathrm{~mm}$, with pinnate forms such as A. acerosa, A. americana, and $M$. flavida thinner than arborescent colonies (Figure 4) such as the Eunicea, Plexaurella, and Pseudoplexaura spp. We also found that linear growth rates negatively correlated with branch thickness $(p<0.001)$; with thicker colonies growing slower and thinner colonies growing faster (Figure 5). Among all studied species, A. acerosa and A. americana were amongst the thinnest species with a mean branch diameter of $2.23(\mathrm{SD}=0.50)$ and $2.87(\mathrm{SD}=0.44)$ $\mathrm{mm}$, respectively (Figure 4) and displayed the fastest linear extension rates (Figure 1).

\section{DISCUSSION}

Long-term monitoring on Caribbean reefs has provided evidence that octocoral populations have grown in the last few decades, at the same time at which scleractinian corals have declined (Ruzicka et al., 2013; Lenz et al., 2015; Tsounis and Edmunds, 2017; Williams et al., 2017; Al-Marayati and Edmunds, 2018). A pattern occurring across the region in reefs as distant as the Florida Keys (Ruzicka et al., 2013), St. John (Tsounis and Edmunds, 2017), and Puerto Rico (Ballantine et al., 2008; Yoshioka, 2009; Williams et al., 2017). A key question that emerges from these studies is what mechanisms allow octocorals to increase in number on shallow forereefs at the same time at which scleractinian corals disappear. A major aspect allowing 


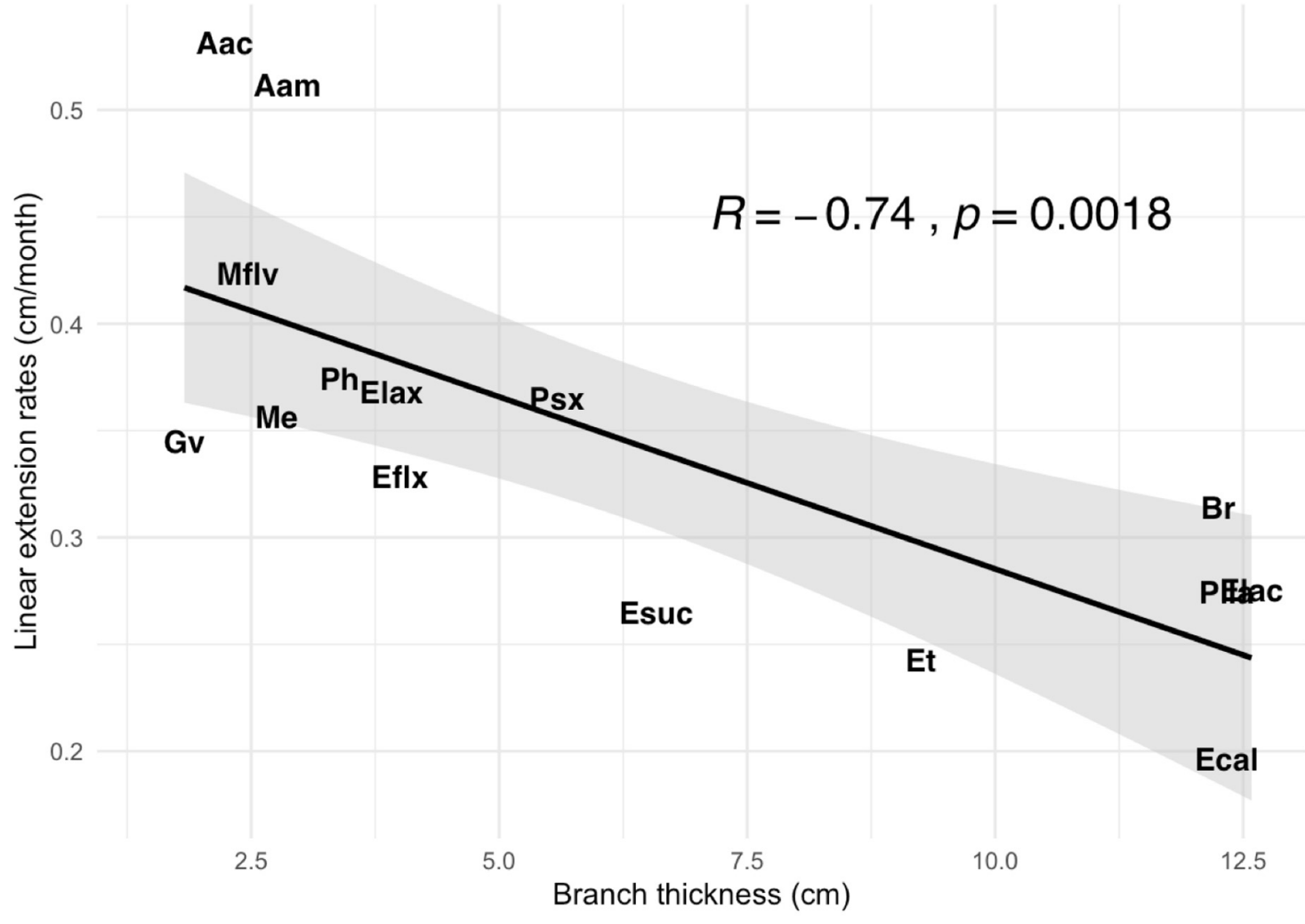

FIGURE 5 | Differences in mean branch thickness $(\mathrm{cm})$ in relationship to mean linear extension rate (cm/month) across species.

octocoral populations to increase over time likely rely on changes in environmental conditions and shifts in the balance of species interactions and their continuous competition for space.

On healthy coral reefs empty space is scarce and benthic dwellers often engage in competition to secure a place (Jackson and Coates, 1986). Some of the strategies to gain a spot on highly competitive benthic coral reefs include the production of harmful chemicals that hurt nearby adult competitors or limit their recruitment (Chadwick and Morrow, 2011), use of specialized structures to fight or digest nearing organisms (Lang, 1973), recruitment in prime areas such as elevations or inclined surfaces (Al-Marayati and Edmunds, 2018), association with symbiotic partners that efficiently remove potential competitors (Dixson et al., 2014) and fast vertical growth rates to explore the relatively empty water column and avoid competition (Yoshioka and Yoshioka, 1991).

Rapid vertical growth facilitates being off the bottom as fast as possible, minimizing the amount of resources committed to competition to maintain a spot on the hard bottom (Hughes and Jackson, 1985; Jackson and Coates, 1986; Yoshioka and Yoshioka, 1991; Sanchez et al., 2004). Here we studied linear extension rates on octocoral species that are now common in most Caribbean shallow forereefs. Our three-year monitoring suggests that species grow at different rates, with plume-like corals growing faster than candelabrum-like or arborescent species. Juveniles (i.e., colonies $<10 \mathrm{~cm}$ ) grow at a faster rate than adults $(>10 \mathrm{~cm})$, and for most species $(58 \%)$, colonies in shallow environments grow faster than in the deepest areas. A key aspect of differences in linear extension rates among species is branch thickness, with thicker colonies growing slower than thinner colonies, suggesting that colony architecture influences growth rates. Below we discuss our results in terms of variation among species, size/age, depth, and thickness as well as provide context of our results for conservation.

\section{Variation in Linear Extension Rates Across Species With Different Branch Thickness}

Our rates range from $6.2 \mathrm{~cm}$ a year for Antillogorgia species to $\sim 2.3 \mathrm{~cm}$ a year for the black sausage coral E. lacinata. These estimates fall within previous reports, suggesting our results represent a general range of linear extension rates for octocorals on Caribbean reefs. For example, Cadena and Sánchez (2010) found that $A$. acerosa in Colombia grew at a rate of $6-18 \mathrm{~cm}$ per year (compared to our $6.2 \mathrm{~cm}$ a year). In contrast albeit for a different species, Castanaro and Lasker (2003) report slower growth rate of $\sim 1.5 \mathrm{~cm}$ a year for $A$. elisabethae in the Bahamas. Kinzie (1974) reports a rate of $2.0 \mathrm{~cm}$ a year for P. homomalla in the Grand Caymans compared to $4.4 \mathrm{~cm}$ per year in our study. Birkeland (1974) reports the same rate as ours $(4.1 \mathrm{~cm}$ a year) for $G$. ventalina in Panama. Our estimates are also similar, albeit faster (3.7 cm per year), to those of Brazeau and Lasker (1992) in Panama for B. asbestinum $(2.2 \mathrm{~cm}$ a year). All differences from 
our mean values and those reported in the literature fall within the standard deviations of our measurements.

In general, we found faster linear extension rates in species with thinner branches. In terms of colony architecture, octocorals display a large range of growth forms, from thin whip-like branches to sausage-like branches (Supplementary Table S2). Our observation that Antilligorgia spp. grow faster correlates with their higher branching rate and thin pinnate growth, which seems to promote faster linear growth rates (Sanchez et al., 2004; Lenihan et al., 2015). Faster growth is possible with narrower, more flexible branches because it allows for increased multidirectional water flow between branches, meaning greater surface areas for gas exchange, particle capture, nutrient uptake, minimal calcium carbonate and tissue deposition horizontally, and photosynthesis by the corals' symbiotic algae (Jokiel, 1978; Khalesi et al., 2007; Lenihan et al., 2015). In contrast, thick colonies such as those of Plexaurella spp. have a much smaller surface to volume ratio, decreasing the number of polyps per unit of area and thus decreasing their feeding potential. In addition, colonies with thick branches have to deposit more calcium carbonate to grow vertically than species with thinner branches, decreasing their ability to ascend out of the benthos rapidly to minimize competitive interactions.

Other ecological and biological attributes such as competition for space, recruitment rates and fertility potential may also facilitate the increase in abundance of fast-growing species on shallow Caribbean forereefs. Fast vertical growers such as the Antillogorgia spp. lessen competition with macroalgae by quickly growing above the macroalgae canopy, gaining access to light and seawater flow (Yoshioka and Yoshioka, 1991; Sanchez et al., 2004). In addition, in Puerto Rico, A. acerosa and A. americana are among the species with the highest recruitment rates (Yoshioka, 1998). Given the widespread disturbances on Caribbean reefs (de Bakker et al., 2019), and the continuous removal of reef species from benthic habitats (Ruzicka et al., 2013; Edmunds and Lasker, 2016), plume-like species may have an advantage to refill these empty spaces and become more common on Caribbean reefs.

Although linear measurements have some limitations for quantifying the growth rate of whole organisms, they are less problematic for arborescent, pinnate or candelabrum like organisms like the sampled octocorals in this study. A major drawback from using linear extensions from single branches to estimate growth rates is that potentially colonies could have small linear extensions but be composed by many branches that, if accounted together, could provide faster growth rates. If this is true, we would expect species with colonies characterized by many branches to have slower growth rates (as they have to share resources across many branches) than species with fewer branches. We observed the opposite. The species with the slowest growth rates, such as the Plexaurella spp., B. asbestinum, E. lacinata, and E. calyculata, are in general characterized by fewer branches (often <10) (Bayer, 1961) than fast-growing species such as the Antillogorgia spp. and M. flavida. Also, our measurements were made on mother branches or principal branches of colonies; Cadena and Sánchez (2010) suggested that these areas have the fastest vertical growth.
A potential limitation of our study is that it contains only data from 2003 to 2006 and given the drastic deterioration of Caribbean reefs in the last decades they are not relevant today. At least three considerations that suggest our rate estimates are relevant. First, previous studies on sclerochronology in scleractinian corals suggest minor variations in growth rates across many decades (Hubbard and Scaturo, 1985; Huston M., 1985) and in many cases the rates are still relevant today (Lough and Cantin, 2014). Second, our estimates fall within previously reported rates for G. ventalina, B. asbestinum, P. homomalla, and A. acerosa (Birkeland, 1974; Kinzie, 1974; Yoshioka and Yoshioka, 1991) suggesting that at least for these four species they have not varied since the 1970's. Third, it is unlikely that linear extension rates in octocorals change without any major rearrangement of the colony architecture (i.e., branches becoming thinner), which to date has not been reported and will likely take at least a few decades of evolutionary change given their generation times ( $>5$ years) (Prada et al., 2008; Prada and Hellberg, 2013; Prada and Hellberg, 2014).

\section{Variation in Linear Extension Rates Across Life History Stages}

For the majority of the octocoral species on this study, small juvenile colonies grew faster than their older adult counterparts in terms of linear extension. This observation is consistent with the fact that smaller individuals are at higher risk of mortality given that reef communities are space-limited with fierce competition for space among organisms (Sebens, 1983). Additionally, small, young individuals are more susceptible than adults to predation by reef dwellers such as fishes, nudibranchs, and urchins. As a result, smaller individuals tend to grow faster until reaching a "safe-size" and then gradually slow down vegetative growth and switch resources to the energetically demanding sexual reproduction in adults (Chornesky and Peters, 1987; Beiring and Lasker, 2000; Watling et al., 2011; Viladrich et al., 2017; Viladrich et al., 2018). This faster growth at smaller younger sizes is clearly visible in our study. The flexiblebranching morphology of octocorals gives them an advantage over hard coral recruits (Bartlett et al., 2018). Given their soft structures and the fact that they have much lower calcification needs to increase vertical growth, octocorals develop quickly from a young age (Bartlett et al., 2018).

\section{Variation in Linear Extension Rates Across Depth}

We found that colonies tend to grow faster in shallow (13 out of 16 species), brighter habitats than in deeper and darker environments. Shallower waters not only receive higher amounts of sunlight for photosynthesis, but are also exposed to higher water motion, increased nutrient levels from available food, metabolites, and gas availability that ultimately enhance coral growth (Lenihan et al., 2015). This availability of resources and sufficient amount of light suggests that colonies in shallow environments will grow faster than in deeper habitats. While in general this appears to be true (Baker and Weber, 1975; Huston M., 1985), there are exceptions in which colonies in 
deep environments can be metabolically sustained by active particle capturing, (i.e., heterotrophy). For example, suspension feeders are generally less affected by changes in light levels due to their continuous feeding via particle capture (Sanchez et al., 1998). Whip-like corals with long, thin branches, such as ellisellids used in the study by Sanchez et al. (1998) and the fast growing Antillogorgia spp. in this study both show fast linear extensions at deeper, darker depths where light is limited than in shallower, brighter depths. All species that we studied engage in symbiosis with dinoflagellates of the family Symbiodiniaceae (van Oppen et al., 2005), and likely derived part of their energy from photosynthetic products, but are also capable of active heterotrophic feeding (Kim and Lasker, 1997). A potential explanation of why they grow faster at depths may be due to the lower number of predators in deeper habitats. In the reefs we sampled, flamingo snails, which are major predators of the sampled octocorals, slightly decrease in abundance with depth (Lucas et al., 2014).

Another factor that may allow faster growth is the more stable conditions (compared to shallow areas) of deeper habitats that allow for stabilized water transparency (Miao and Xie, 2007). In shallower waters there is a greater variability of transparency due to fluctuating conditions of water movement, runoff, rainfall, pollution, and sedimentation, which change the amount of light passing through the surface and available for the zooxanthellae to perform photosynthesis (Manikandan et al., 2016). These changes may cause added stress to the corals housing more photosensitive algal species in the shallow sites, while the coral species that extend most rapidly at those sites may contain algae that have a lesser susceptibility to photoinhibition and variation (Bhagooli and Hidaka, 2004). Understanding what factors affect octocoral growth rates at different depths is crucial to understand what kind of corals are more vulnerable to the continuously deteriorating environments. As shown by long-term monitoring (Ruzicka et al., 2013; Lenz et al., 2015; Williams et al., 2017), it seems that environmental degradation is having less detrimental effect on octocoral communities (while removing heavy calcifies such as hard corals), particularly in shallow water environments.

\section{Implications for Coral Reef Conservation}

Fast linear growth in octocorals as reported here may minimize competition with macroalgae and other benthic dwellers, allowing them to rapidly escape from the benthos, rather than engaging in continuous competitive interactions such as in most scleractinians corals (Box and Mumby, 2007; Steve and Peter, 2007). In the Caribbean, only the acroporid species are on par with the linear extension of octocorals (Bak et al., 2009), and generally scleractinians are more heavily affected by increased temperature and bleaching (Prada et al., 2010; Thornhill et al., 2011) and macroalgal competition (Box and Mumby, 2007) than are octocorals (Maida et al., 1995; Lasker et al., 2003).

Continued monitoring of growth rates will be critical to understanding how various reef species are differentially affected, and in what directions benthic communities will change. Our data opens up the possibility that fast-growing, plumelike octocorals may become dominant on Caribbean shallow forereefs as a result of the continual removal of scleractinian corals due to climate change. The high standard deviations from this study indicate that local environmental factors could have influenced the results, further suggesting the need for additional experimentation. Given the continued change of Caribbean shallow forereefs from scleractinian-rich communities to octocoral forests, it is essential to quantify how fish communities and other reef dwellers are responding to these newly accessible habitats.

\section{DATA AVAILABILITY STATEMENT}

The datasets generated for this study are available on request to the corresponding author.

\section{ETHICS STATEMENT}

The studies involving human participants were reviewed and approved by the Gibson Institute of Cognitive Research Institutional Review Board (IRB). Written informed consent to participate in this study was provided by the participants' legal guardian/next of kin. Written informed consent was obtained from the individual(s) and/or minor(s) parent for the publication of any potentially identifiable images or data included in this article.

\section{AUTHOR CONTRIBUTIONS}

CP and DB recorded growth rates in the field. NB analyzed all data and generated all the figures, and statistical analysis with DB. CP and NB wrote the manuscript with continuous feedback from DB, All authors contributed to the article and approved the submitted version.

\section{FUNDING}

This work was supported by the NOAA Coral Reef Ecosystems Studies Project. CP was funded by an Earl S. Tupper fellowship from the Smithsonian Tropical Research Institute and start-up funds from the College of the Environment and Life Sciences from the University of Rhode Island.

\section{ACKNOWLEDGMENTS}

We would like to thank the Coastal and Environmental Fellowship Program at the University of Rhode Island. We thank Paul Yoshioka for initiating this project and to the University of Puerto Rico in Mayagüez. We would also like to thank Cielo Montoya for illustrations in Supplementary Table S2.

\section{SUPPLEMENTARY MATERIAL}

The Supplementary Material for this article can be found online at: https://www.frontiersin.org/articles/10.3389/fmars.2020. 00483/full\#supplementary-material 


\section{REFERENCES}

Al-Marayati, M., and Edmunds, P. J. (2018). Octocoral distribution is associated with substratum orientation on coral reefs in St. John, U.S. Virgin Islands. J. Exp. Mar. Biol. Ecol. 500, 55-62. doi: 10.1016/j.jembe.2017.12.015

Anderson, K. D., Cantin, N. E., Heron, S. F., Pisapia, C., and Pratchett, M. S. (2017). Variation in growth rates of branching corals along Australia's Great Barrier Reef. Sci. Rep. 7:2920.

Ateweberhan, M., Feary, D. A., Keshavmurthy, S., Chen, A., Schleyer, M. H., and Sheppard, C. R. C. (2013). Climate change impacts on coral reefs: synergies with local effects, possibilities for acclimation, and management implications. Mar. Pollut. Bull. 74, 526-539. doi: 10.1016/j.marpolbul.2013.06.011

Bak, R., Nieuwland, G., and Meesters, E. (2009). Coral growth rates revisited after 31 years: What is causing lower extension rates in Acropora palmata? Bull. Mar. Sci. 84, 287-294.

Baker, P. A., and Weber, J. N. (1975). Coral growth rate: variation with depth. Earth Planet. Sci. Lett. 27, 57-61. doi: 10.1016/0012-821x(75)90160-0

Ballantine, D. L., Appeldoorn, R. S., Yoshioka, P., Weil, E., Armstrong, R., Garcia, J. R., et al. (2008). "Biology and ecology of Puerto Rican coral reefs," in Coral Reefs of the USA, eds B. M. Riegl and R. E. Dodge (Dordrecht: Springer), 375-406. doi: 10.1007/978-1-4020-6847-8_9

Bartlett, L., Brinkhuis, V., Ruzicka, R., Colella, M., Lunz, K., Leone, E., et al. (2018). "Dynamics of stony coral and octocoral juvenile assemblages following disturbance on patch reefs of the Florida reef tract," in Corals in a Changing World, eds C. Duque Beltran, and E. Tello Camacho (Rijeka: IntechOpen), 99-120.

Bayer, F. M. (1961). The Shallow-Water Octocorallia of the West Indian Region. A Manual for marine biologists. The Hague: Martinus Nijhoff.

Beiring, E., and Lasker, H. (2000). Egg production by colonies of a gorgonian coral. Mar. Ecol. Prog. Ser. 196, 169-177. doi: 10.3354/meps196169

Ben-Zvi, O., Tamir, R., Keren, N., Berman-Frank, I., Kolodny, Y., Benaltabet, T., et al. (2020). Photophysiology of a mesophotic coral 3 years after transplantation to a shallow environment. Coral Reefs. doi: 10.1007/s00338020-01910-0

Bhagooli, R., and Hidaka, M. (2004). Photoinhibition, bleaching susceptibility and mortality in two scleractinian corals, Platygyra ryukyuensis and Stylophora pistillata, in response to thermal and light stresses. Comp. Biochem. Physiol. Part A Mol. Integr. Physiol. 137, 547-555. doi: 10.1016/j.cbpb.2003.11.008

Birkeland, C. (1974). The effect of wave action on the populatlon dynamics of Gorgonia ventalina Linnaeus. Stud. Trop. Oceanogr. 12, 115-126.

Box, S., and Mumby, P. (2007). Effect of macroalgal competition on growth and survival of juvenile Caribbean corals. Mar. Ecol. Prog. Ser. 342, 139-149. doi: 10.3354/meps342139

Brazeau, D. A., and Lasker, H. R. (1992). Growth rates and growth strategy in a clonal marine invertebrate, the Caribbean octocoral Briareum asbestinum. Biol. Bull. 183, 269-277. doi: 10.2307/1542214

Cabral-Tena, R., López-Pérez, A., Reyes-Bonilla, H., Calderon-Aguilera, L., Orión, N. L., Rodriguez Zaragoza, F., et al. (2018). Calcification of coral assemblages in the eastern Pacific: reshuffling calcification scenarios under climate change. Ecol. Indic. 95, 726-734. doi: 10.1016/j.ecolind.2018.08.021

Cadena, N. J., and Sánchez, J. A. (2010). Colony growth in the harvested octocoral Pseudopterogorgia acerosa in a Caribbean coral reef. Mar. Ecol. 31, 566-573. doi: 10.1111/j.1439-0485.2010.00397.x

Castanaro, J., and Lasker, H. R. (2003). Colony growth responses of the Caribbean octocoral, Pseudopterogorgia elisabethae, to harvesting. Invertebr. Biol. 122, 299-307. doi: 10.1111/j.1744-7410.2003.tb00094.x

Chadwick, N. E., and Morrow, K. M. (2011). "Competition among sessile organisms on coral reefs," in Coral Reefs: An Ecosystem in Transition, eds Z. Dubinsky and N. Stambler (Dordrecht: Springer), 347-371. doi: 10.1007/97894-007-0114-4_20

Chornesky, E. A., and Peters, E. C. (1987). Sexual reproduction and colony growth in the scleractinian coral Porites astreoides. Biol. Bull. 172, 161-177. doi: 10. $2307 / 1541790$

Connell, J. (1973). "Population ecology of reef-building corals," in Biology and Geology of Coral Reefs, eds A. Jones and R. Endeam (London: Academic Press), 205-245. doi: 10.1016/b978-0-12-395526-5.50015-8

Cortés, J., and Reyes-Bonilla, H. (2017). "Human influences on eastern tropical Pacific coral communities and coral reefs," in Coral Reefs of the Eastern Tropical
Pacific: Persistence and Loss in a Dynamic Environment, eds P. W. Glynn, D. P. Manzello, and I. C. Enochs (Dordrecht: Springer), 549-563. doi: 10.1007/97894-017-7499-4_20

Costanza, R., Groot, R., Sutton, P., Van Der Ploeg, S., Anderson, S., Kubiszewski, I., et al. (2014). Changes in the global value of ecosystem services. Glob. Environ. Change 26, 152-158.

de Bakker, D. M., Van Duyl, F. C., Perry, C. T., and Meesters, E. H. (2019). Extreme spatial heterogeneity in carbonate accretion potential on a Caribbean fringing reef linked to local human disturbance gradients. Glob. Change Biol. 25, 4092-4104. doi: $10.1111 /$ gcb. 14800

De Mendiburu, F. (2009). Una Herramienta de Analisis Estadistico Para la Investigacion Agricola. Ph.D. thesis, Universidad Nacional Agraria La Molina, Rimac.

Dixson, D., Abrego, D., and Hay, M. (2014). Chemically mediated behavior of recruiting corals and fishes: a tipping point that may limit reef recovery. Science 345, 892-897. doi: 10.1126/science. 1255057

Edmunds, P. J. (2013). Decadal-scale changes in the community structure of coral reefs of St. John, US Virgin Islands. Mar. Ecol. Prog. Ser. 489, 107-123. doi: 10.3354/meps10424

Edmunds, P. J., and Lasker, H. R. (2016). Cryptic regime shift in benthic community structure on shallow reefs in St. John, US Virgin Islands. Mar. Ecol. Prog. Ser. 559, 1-12. doi: 10.3354/meps 11900

Forsman, Z. H., Page, C. A., Toonen, R. J., and Vaughan, D. (2015). Growing coral larger and faster: micro-colony-fusion as a strategy for accelerating coral cover. PeerJ 3:e1313. doi: 10.7717/peerj.1313

Gabay, Y., Fine, M., Barkay, Z., and Benayahu, Y. (2014). Octocoral tissue provides protection from declining oceanic pH. PLoS One 9:e91553. doi: 10.1371/journal. pone.0091553

Gómez, C. E., Paul, V. J., Ritson-Williams, R., Muehllehner, N., Langdon, C., and Sánchez, J. A. (2015). Responses of the tropical gorgonian coral Eunicea fusca to ocean acidification conditions. Coral Reefs 34, 451-460. doi: 10.1007/s00338014-1241-3

Goulet, T. L., Shirur, K. P., Ramsby, B. D., and Iglesias-Prieto, R. (2017). The effects of elevated seawater temperatures on Caribbean gorgonian corals and their algal symbionts, Symbiodinium spp. PLoS One 12:e0171032. doi: 10.1371/ journal.pone.0171032

Green, D. H., Edmunds, P. J., and Carpenter, R. C. (2008). Increasing relative abundance of Porites astreoides on Caribbean reefs mediated by an overall decline in coral cover. Mar. Ecol. Prog. Ser. 359, 1-10. doi: 10.3354/meps07454

Hagedorn, M., Page, C. A., O'neil, K., Flores, D. M., Tichy, L., Chamberland, V. F., et al. (2018). Successful demonstration of assisted gene flow in the threatened coral Acropora palmata across genetically-isolated Caribbean populations using cryopreserved sperm. bioRxiv [Preprint]. doi: 10.1101/492447

Hoegh-Guldberg, O., Mumby, P., Hooten, A. J., Steneck, R. S., Greenfield, P., Gomez, E., et al. (2008). Coral reefs under rapid climate change and ocean acidification. Science 318, 1737-1742.

Hothorn, T., Bretz, F., and Westfall, P. (2008). Simultaneous inference in general parametric models. Biom. J. 50, 346-363. doi: 10.1002/bimj.200810425

Hubbard, D. K., and Scaturo, D. (1985). Growth rates of seven species of scleractinean corals from Cane Bay and Salt River, St. Croix, USVI. Bull. Mar. Sci. 36, 325-338.

Hughes, T. P., and Connell, J. H. (1987). Population dynamics based on size or age? A reef-coral analysis. Am. Nat. 129, 818-829. doi: 10.1086/284677

Hughes, T. P., and Jackson, J. B. C. (1985). Population dynamics and life histories of foliaceous corals. Ecol. Monogr. 55, 141-166. doi: 10.2307/1942555

Hughes, T. P., Kerry, J. T., Baird, A. H., Connolly, S. R., Dietzel, A., Eakin, C. M., et al. (2018). Global warming transforms coral reef assemblages. Nature 556, 492-496. doi: 10.1038/s41586-018-0041-2

Huston, M. A. (1985). Patterns of species diversity on coral reefs. Annu. Rev. Ecol. Syst. 16, 149-177. doi: 10.1146/annurev.es.16.110185.001053

Huston, M. (1985). Variation in coral growth rates with depth at Discovery Bay, Jamaica. Coral Reefs 4, 19-25. doi: 10.1007/bf00302200

Jackson, J., Donovan, M., Cramer, K., and Lam, V. (2014). Status and Trends of Caribbean Coral Reefs: 1970-2012 Global Coral Reef Monitoring Network. Gland: IUCN.

Jackson, J. B. C., and Coates, A. G. (1986). Life cycles and evolution of clonal (modular) animals. Philos.Trans. R. Soc. Lond. Ser. B Biol. Sci. 313:7. doi: $10.1098 /$ rstb.1986.0022 
Jokiel, P. L. (1978). Effects of water motion on reef corals. J. Exp. Mar. Biol. Ecol. 35, 87-97. doi: 10.1016/0022-0981(78)90092-8

Khalesi, M. K., Beeftink, H. H., and Wijffels, R. H. (2007). Flow-dependent growth in the zooxanthellate soft coral Sinularia flexibilis. J. Exp. Mar. Biol. Ecol. 351, 106-113. doi: 10.1016/j.jembe.2007.06.007

Kim, K., and Lasker, H. R. (1997). Flow-mediated competition among suspension feeding gorgonians. J. Exp. Mar. Biol. Ecol. 215, 49-64. doi: 10.1016/s00220981(97)00015-4

Kinzie, R. A. (1974). Plexaura homomalla: the biology and ecology of a hawestable resource. Stud. Trop. Oceanogr. 111, 22-38.

Lang, J. C. (1973). Interspecific aggression by scleractinian corals. II. Why the race is not always to the swift. Bull. Mar. Sci. 23, 260-279.

Lasker, H. R., Boller, M. L., Castanaro, J., and Sanchez, J. A. (2003). Determinate growth and modularity in a gorgonian octocoral. Biol. Bull. 205, 319-330. doi: $10.2307 / 1543295$

Lenihan, H. S., Hench, J. L., Holbrook, S. J., Schmitt, R. J., and Potoski, M. (2015). Hydrodynamics influence coral performance through simultaneous direct and indirect effects. Ecology 96, 1540-1549. doi: 10.1890/14-1115.1

Lenz, E. A., Bramanti, L., Lasker, H. R., and Edmunds, P. J. (2015). Long-term variation of octocoral populations in St. John, US Virgin Islands. Coral Reefs 34, 1099-1109. doi: 10.1007/s00338-015-1315-x

Lesser, M. P., Ojimi, M., Gates, R., Stat, M., Slattery, M., and Grottoli, A. G. (2010). Photoacclimatization by the coral Montastraea cavernosa in the mesophotic zone: Light, food, and genetics. Ecology 91, 990-1003. doi: 10.1890/090313.1

Lough, J. M., and Cantin, N. E. (2014). Perspectives on massive coral growth rates in a changing ocean. Biol. Bull. 226, 187-202. doi: 10.1086/bblv226n 3 p187

Lucas, M. Q., Rodriguez, L. R., Sanabria, D. J., and Weil, E. (2014). Natural prey preferences and spatial variability of predation pressure by Cyphoma gibbosum (Mollusca: Gastropoda) on octocoral communities off La Parguera, Puerto Rico. Int. Sch. Res. Notices 2014:742387.

Maida, M., Sammarco, P. W., and Coll, J. C. (1995). Effects of soft corals on scleractinian coral recruitment: directional allelopathy and inhibition of settlement. Mar. Ecol. Prog. Ser. 121, 191-202. doi: 10.3354/meps121191

Manikandan, B., Jeyaraman, R., Mohan, H., Rengaiyan, P., Murali, M., and Ingole, B. (2016). Community structure and coral health status across the depth gradients of Grande Island, Central west coast of India. Reg. Stud. Mar. Sci. 7, $150-158$.

Miao, Z.-Q., and Xie, Y.-H. (2007). Effects of water-depth on hydrodynamic force of artificial reef. J. Hydrodyn. Ser. B 19, 372-377. doi: 10.1016/s1001-6058(07) 60072-9

Pandolfi, J. M., Jackson, J. B. C., Baron, N., Bradbury, R. H., Guzman, H. M., Hughes, T. P., et al. (2005). Are U.S. coral reefs on the slippery slope to slime? Science 307, 1725-1726. doi: 10.1126/science.1104258

Pinheiro, J. C., Bates, D. J., DebRoy, S., and Sakar, D. (2012). The Nlme Package: Linear and Nonlinear Mixed Effects Models, $R$ Version 3.

Prada, C., and Hellberg, M. E. (2013). Long prereproductive selection and divergence by depth in a Caribbean candelabrum coral. Proc. Natl. Acad. Sci. U.S.A. 110, 3961-3966. doi: 10.1073/pnas. 1208931110

Prada, C., and Hellberg, M. E. (2014). Strong natural selection on juveniles maintains a narrow adult hybrid zone in a broadcast spawner. Am. Nat. 184, 702-713. doi: $10.1086 / 678403$

Prada, C., Schizas, N. V., and Yoshioka, P. M. (2008). Phenotypic plasticity or speciation? A case from a clonal marine organism. BMC Evol. Biol. 8:47. doi: 10.1186/1471-2148-8-47

Prada, C., Weil, E., and Yoshioka, P. M. (2010). Octocoral bleaching during unusual thermal stress. Coral Reefs 29, 41-45. doi: 10.1007/s00338-009-0547-z

R Development Core Team (2008). R: A Language and Environment for Statistical Computing. Vienna: R Foundation for Statistical Computing.

Ruzicka, R., Colella, M., Porter, J., Morrison, J., Kidney, J., Brinkhuis, V., et al. (2013). Temporal changes in benthic assemblages on Florida Keys reefs 11 years after the 1997/1998 El Niño. Mar. Ecol. Prog. Ser. 489, 125-141. doi: $10.3354 /$ meps 10427

Sala, E., and Knowlton, N. (2006). Global marine biodiversity trends. Annu. Rev. Environ. Resour. 31, 93-122.
Sanchez, J. A., Lasker, H., Nepomuceno, E., Sánchez, J., and Woldenberg, M. (2004). Branching and self-organization in marine modular colonial organisms: a model. Am. Nat. 163, E24-E39.

Sanchez, J. A., and Wirshing, H. H. (2005). A field key to the identification of tropical western Atlantic zooxanthellate octocorals (Octocorallia: Cnidaria). Caribb. J. Sci. 41, 508-522.

Sanchez, J. A., Zea, S., and Diaz, J. (1998). Patterns of octocoral and black coral distribution in the oceanic barrier reef-complex of Providencia Island, southwestern Caribbean. Caribb. J. Sci. 34, 250-264.

Sebens, K. P. (1983). The larval and juvenile ecology of the temperate octocoral Alcyonium siderium Verrill. I. Substratum selection by benthic larvae. J. Exp. Mar. Biol. Ecol. 71, 73-89. doi: 10.1016/0022-0981(83)90105-3

Sebens, K. P., and Done, T. J. (1992). "Water flow, growth form and distribution of scleractinian corals: Davies Reef, (GBR), Australia," in Proceedings of the Seventh International Coral Reef Symposium, Vol. 1 (Guam: University of Guam Press), 557-568.

Steve, J. B., and Peter, J. M. (2007). Effect of macroalgal competition on growth and survival of juvenile Caribbean corals. Mar. Ecol. Prog. Ser. 342, 139-149.

Thornhill, D. J., Rotjan, R. D., Todd, B. D., Chilcoat, G. C., Iglesias-Prieto, R., Kemp, D. W., et al. (2011). A connection between colony biomass and death in Caribbean reef-building corals. PLoS One 6:e29535. doi: 10.1371/journal.pone. 0029535

Tsounis, G., and Edmunds, P. J. (2017). Three decades of coral reef community dynamics in St. John, USVI: a contrast of scleractinians and octocorals. Ecosphere 8:e01646. doi: 10.1002/ecs2.1646

van Oppen, M. J. H., Mieog, J. C., Sánchez, C. A., and Fabricius, K. E. (2005). Diversity of algal endosymbionts (zooxanthellae) in tropical octocorals: the roles of geography and host relationships. Mol. Ecol. 14, 2403-2417. doi: 10. 1111/j.1365-294x.2005.02545.x

Viladrich, N., Bramanti, L., Tsounis, G., Martínez-Quitana, A., Ferrier-Pagès, C., and Rossi, S. (2017). Variation of lipid and free fatty acid contents during larval release in two temperate octocorals according to their trophic strategy. Mar. Ecol. Prog. Ser. 573, 117-128. doi: 10.3354/meps12141

Viladrich, N., Gori, A., and Gili, J. M. (2018). Fast growth rate in a young colony of the Mediterranean gorgonian Eunicella singularis. Mar. Biodivers. 48, 951-952. doi: 10.1007/s12526-016-0554-6

Watling, L., France, S. C., Pante, E., and Simpson, A. (2011). Chapter two biology of deep-water Octocorals. Adv. Mar. Biol. 60, 41-122. doi: 10.1016/b978-0-12385529-9.00002-0

Wells, S., Ravilious, C., and Corcoran, E. (2006). In the Front Line: Shoreline Protection and Other Ecosystem Services from Mangroves and Coral Reefs. Cambridge: United Nations Environment Programme.

Williams, S. M., Sánchez-Godínez, C., Newman, S. P., and Cortés, J. (2017). Ecological assessments of the coral reef communities in the Eastern Caribbean and the effects of herbivory in influencing coral juvenile density and algal cover. Mar. Ecol. 38:e12395. doi: 10.1111/maec.12395

Yoshioka, P. (1998). Variable recruitment and its effects on the population and community structure of shallow-water gorgonians. Bull. Mar. Sci. 59, 433-443.

Yoshioka, P. (2009). Sediment transport and the distribution of shallow-water gorgonians. Caribb. J. Sci. 45, 254-259. doi: 10.18475/cjos.v45i2.a12

Yoshioka, P. M., and Yoshioka, B. B. (1991). A comparison of the survivorship and growth of shallow-water gorgonian species of Puerto Rico. Mar. Ecol. Prog. Ser. 69, 253-260. doi: 10.3354/meps069253

Zuur, A., Ieno, E. N., Walker, N., Saveliev, A., and Smith, G. M. (2009). Mixed Effects Models and Extensions in Ecology With R. Cham: Springer.

Conflict of Interest: The authors declare that the research was conducted in the absence of any commercial or financial relationships that could be construed as a potential conflict of interest.

Copyright (c) 2020 Borgstein, Beltrán and Prada. This is an open-access article distributed under the terms of the Creative Commons Attribution License (CC BY). The use, distribution or reproduction in other forums is permitted, provided the original author(s) and the copyright owner(s) are credited and that the original publication in this journal is cited, in accordance with accepted academic practice. No use, distribution or reproduction is permitted which does not comply with these terms. 